\title{
A Different Point of View of Plant-Bacterial Interactions: RNA-Seq Analysis of a PGP Bacterial Endophyte Colonizing Rapeseed Plants ${ }^{\dagger}$
}

\author{
Zaki Saati-Santamaría ${ }^{1,2, *(D)}$, Daniel Kumazawa Morais ${ }^{3}\left(\mathbb{D}\right.$, Vojtěch Tláskal ${ }^{3}$, Oldřich Benada $^{3}(\mathbb{D}$, \\ Olga Kofroňová ${ }^{3}$, Alejandro Jiménez-Gómez ${ }^{1} \mathbb{D}$, Peter Baldrian ${ }^{3}\left(\mathbb{D}\right.$, Raúl Rivas ${ }^{1,2,4}$ (D) and \\ Paula García-Fraile 1,2,4 (D)
}

check for updates

Citation: Saati-Santamaría, Z. Morais, D.K.; Tláskal, V.; Benada, O.; Kofroňová, O.; Jiménez-Gómez, A.; Baldrian, P.; Rivas, R.; García-Fraile, P. A Different Point of View of Plant-Bacterial Interactions: RNA-Seq Analysis of a PGP Bacterial Endophyte Colonizing Rapeseed Plants. Biol. Life Sci. Forum 2021, 4, 90. https://doi.org/10.3390/IECPS202008726

Academic Editor:

Yoselin Benitez-Alfonso

Published: 1 December 2020

Publisher's Note: MDPI stays neutral with regard to jurisdictional claims in published maps and institutional affiliations.

Copyright: (c) 2020 by the authors. Licensee MDPI, Basel, Switzerland. This article is an open access article distributed under the terms and conditions of the Creative Commons Attribution (CC BY) license (https:// creativecommons.org/licenses/by/ $4.0 /)$.
1 Microbiology and Genetics Department, University of Salamanca, 37007 Salamanca, Spain; alexjg@usal.es (A.J.-G.); raulrg@usal.es (R.R.); paulagf81@usal.es (P.G.-F.)

2 Institute for Agribiotechnology Research (CIALE), 37007 Salamanca, Spain

3 Institute of Microbiology of the Czech Academy of Sciences, 14220 Praha, Czech Republic; daniel.morais@brmicrobiome.org (D.K.M.); vojtech.tlaskal@natur.cuni.cz (V.T.); benada@biomed.cas.cz (O.B.); kofra@biomed.cas.cz (O.K.); baldrian@biomed.cas.cz (P.B.)

4 Associated Research Unit, USAL-CSIC (IRNASA), 37008 Salamanca, Spain

* Correspondence: zakisaati@usal.es

+ Presented at the 1st International Electronic Conference on Plant Science, 1-15 December 2020; Available online: https:/ /iecps2020.sciforum.net/.

Keywords: plant-bacteria interactions; RNA-Seq; Pseudomonas; rapeseed; roots

Some microbes are important players in plant fitness, contributing to their nutrient acquisition and protection against diverse biotic and abiotic stresses [1]. Despite the vast knowledge acquired during recent decades about the effects in plants of plant growthpromoting (PGP) bacteria [2], apart from those of the legume-rhizobial interactions [3], not much is known about the response of bacteria to the interaction with the plant. With the aim to decipher the transcription profile of a non-rhizobial strain in its interaction with the plant, a PGP Pseudomonas strain isolated from Brassica napus roots and capable of protecting the plant from biotic and abiotic stresses was inoculated onto rapeseed seedlings. Eleven days post-inoculation, we obtained the RNA-Seq profile of bacterial cells colonizing the seedlings' roots. RNA from free living cells was used as a control. Our analyses allowed us to identify 1378 differentially expressed bacterial genes (log2 fold change $>2$; adjusted $p$ value $<0.05$ ). The most overexpressed genes in the interaction are related to biofilm formation, bacterial immunity and infection and bacterial resistance to antimicrobial compounds, likely excreted by the plant. However, genes implicated in PGP traits which had been previously demonstrated in vitro for this strain appeared to be not significantly overexpressed, suggesting a latter PGP action in the interaction. Based on this RNA-Seq experiment, our results shed light on bacterial mechanisms to effectively colonize plant roots, to survive plant defense mechanisms, and to promote plant immunity.

Supplementary Materials: The poster presentation is available online at https: / / www.mdpi.com/ article/10.3390/IECPS2020-08726/s1.

Funding: This work was funded from the European Union's Horizon 2020 research and innovation programme under grant agreement No. 750795. 


\section{References}

1. Menendez, E.; Garcia-Fraile, P. Plant probiotic bacteria: Solutions to feed the world. AIMS Microbiol. 2017, 3, 502. [CrossRef] [PubMed]

2. Hayat, R.; Ali, S.; Amara, U.; Khalid, R.; Ahmed, I. Soil beneficial bacteria and their role in plant growth promotion: A review. Ann. Microbiol. 2010, 60, 579-598. [CrossRef]

3. Oldroyd, G.E.; Murray, J.D.; Poole, P.S.; Downie, J.A. The rules of engagement in the legume-rhizobial symbiosis. Annu. Rev. Genet. 2011, 45, 119-144. [CrossRef] 